\title{
The Effect of Listening Music on Reaction Time of Badminton Players
}

\author{
Adnyana Putra \\ Faculty of Sports and Health \\ Universitas Pendidikan Ganesha \\ Singaraja, Indonesia \\ adnyanaputra@undiksha.ac.id
}

\author{
Ni Made Sri Dewi Lestari \\ Faculty of Sports and Health \\ Universitas Pendidikan Ganesha \\ Singaraja, Indonesia \\ animadesridewi@undiksha.ac.id
}

\author{
Putu Adi Suputra \\ Faculty of Sports and Health \\ Universitas Pendidikan Ganesha \\ Singaraja, Indonesia \\ putuadisuputra@undiksha.ac.id
}

\begin{abstract}
This study aimed to investigate the effect of listening to music on reaction time of members of Undiksha badminton student activity units. Study design was employed was experimental research. A of total 28 people were used as subjects of the research and they were further divided into 3 treatment groups: do not listen to music (control), fast tempo music, and slow tempo music. As soon as the subjects were undergoing treatment, the reaction time was measured up to 10 times. This procedure was repeated 3 times. The Type of reaction time employed was simple reaction time (visual and audio). Description data of audio reaction time were: control (mean (r) $=339.58 \mathrm{~ms}$ and standard deviation $(\mathrm{SD})=46.99)$; fast tempo music $(r=363.15 \mathrm{~ms}$ and $S D=62.64)$; and slow tempo music $(r=$ 352.37 and $\mathrm{SD}=\mathbf{8 4 . 3 0})$. Description data of visual reaction time were: control $(r=316.58 \mathrm{~ms}$ and $\mathrm{SD}=45.01)$; fast tempo music $(r$ $=335.34 \mathrm{~ms}$ and $\mathrm{SD}=\mathbf{6 0 . 9 6})$; and slow tempo music $(r=323,86$ and $S D=61.46)$. Based on the test results and ANOVA analysis, it was discovered that among the three groups the results were not significant, both audio $(p=0.829)$ and visual $(p=0.846)$ reaction time. It was concluded that after listening to music, there is no significant effect on reaction time of members of Undiksha badminton student activity units.
\end{abstract}

Keywords-badminton, music tempo, reaction time

\section{INTRODUCTION}

Achievements in sports are generally influenced by three factors. These three factors include physical, technical, and mental factors. In the determination of achievement, badminton, as one kind of sport, could also not be separated from those three factors. On physical factors, reaction time is one of the important factors that determine a player's response in front of an attack or action from the opponent. In a game, the lower the reaction time a person has, the easier or faster he or she responds to the action of the opponent. In general, the reaction time varies from individual to individual. Currently, many studies focus on factors that are related to reaction time.

While doing exercises, people sometimes do some activity or ritual in order to support their mental readiness in exercising. One such activity is listening to music. Listening to music is often done by people while participating in sporting activities, especially when jogging. Rhythm in music plays a role in how the human brain works. Listening to music has been observed to influence motivation so that its achievement becomes farther, but in other studies, music sometimes does not affect the aspect of endurance. It can be concluded that the effect of listening to music does not last long.

Universitas Pendidikan Ganesha (Undiksha) is one of the universities in Indonesia that have a student's activity unit (SAU) on badminton which accommodates students' interest in badminton sport. Currently, the SAU has 28 active students as members. A total of 9 people $(32.14 \%)$ were badminton athletes, where 3 of them $(33.3 \%)$ were athletes from the district level and 6 (66.7\%) were athletes from the provincial/regency level.

Based on the results of the questionnaires obtained from members of SAU that are still active, it was found that all of them like to listen to music, though about 75\% never listen to music just before the game. Generally, they listen to music while jogging, resting, or before they go to bed. The music they listen to generally varies from slow to fast tempo.

Reaction time is the time required to respond to a given stimulus. Thus, the lesser time it takes, the faster the reaction and vice versa. There are three types of reaction time in this experiment, and they are (Kosinski):

a. Simple reaction time or simple reaction time experiments. This means that there is only one stimulus and one response. For example, give an $\mathrm{X}$ at a location, mark the dot, and react to the sound.

b. Recognition reaction time experiments. This means that there are some stimuli that should be given a response, and there is a stimulus that should not be given a response (distractor set). There is only one correct response. For example "symbol recognition" and "tone recognition".

c. Choice reaction time experiments, which must provide a stimulus that corresponds to the stimulus, for example pressing a button associated with the letter if the letter is visible on the screen.

In general, the average simple reaction time for an individual's college age is about 190 milliseconds $(0.19$ seconds) for light stimulus and about 160 milliseconds (0.16 seconds) for sound stimulus. The average recognition reaction time is about 384 milliseconds. Donders (in Kosinski) through his research mentioned that the simple reaction time is faster than the recognition reaction time, and the choice reaction time value is the slowest or the longest. A conclusion can be reached that complex stimuli takes longer time because it requires longer processing time, although when looked at from the 
perspective of muscle preparation and muscle movement there is requirement for relatively the same time.

Hick (in Kosinski), based on research on choice reaction time states that the relationship between reaction time and the number of different stimuli is logarithmic. This means that there is increment in reaction time based on increasing number of possible stimuli. But at some point when the amount of the stimuli have been large enough, then only a little reaction time increases. Reaction time ranges from 420 milliseconds to one appropriate stimulus up to 630 milliseconds to 6 (six) appropriate stimuli, which increases approximately 40 milliseconds for each item added to the memory set. There are confirmations from various researchers that reaction to sound is faster than the reaction to light, with an average auditory reaction time of about 140-160 milliseconds and a visual reaction time of about 180-220 milliseconds. Judging from the intensity of both visual and auditory stimuli, the longer the duration of the stimulus the smaller its reaction time. It was also found that the stronger the intensity of the stimulus, the smaller its reaction time. At one point, however, the increase in power of the stimulus does not have a significant effect on reaction time. In this case, when the point has been exceeded, the reaction time is constant (Kosinski).

\section{Some factors that affect reaction time include (Kosinski):}

a. Degree of anxiety or tension: situations where an individual is too relaxed or too tense causes reaction time to be longer. The best situation is when the anxiety is in the moderate level which causes the reaction time to be maximal. Research carried out by Masanobu and Choshi (2006) mentioned that the degree of muscle tension affects brain activities. Muscle tension in the medium level (10\% maximum) makes the brain work faster or be in more alert.

b. Age: The timing of a simple reaction is smaller from infancy to age of 20s, then decreases slowly to the age of 5060 years, and eventually declines rapidly when attaining the age of 70 years and above. Increasing age also affects increasing variation of reaction time.

c. Gender: In almost all age groups reaction time in men is smaller than in women and this cannot be maneuvered through exercise. [10] found that gradual dehydration (weight loss of $2.6 \%$ in the last 7 days) caused women to have their reaction time elongated, but in men it shortened the reaction time.

d. Left vs Right Hand: Based on the results of several studies on the type of reaction time by means of indicating individual target, it was discovered that individual with left hand tendency has a lower reaction time than individual with right hand tendency. This is due to the fact that in individuals with left hand tendency, the right hemisphere is more active because of some specialization functions one of which is the function of spatial relations or spatial relationships.

e. Other factors such as central vision vs. edge, exercise, fatigue, fasting, distraction, alertness of stimulus, presentation sequence, breathing cycle, finger tremor, personality type, exercise, stress and punishment, stimulant medications, intelligence, learning disorders, brain injury, and illness also affect reaction time.

[7] came up with the result that individuals who listen to music have a smaller error rate in responding to certain stimuli compared to individuals who do not listen to music. [8] got the result that music with fast tempo makes the emotional level of individual increases.

Based on the above exposure, the research team carried out a study on the effect of listening to music on reaction time on the members of SAU Badminton Undiksha.

\section{RESEARCH METHODS}

The type of research employed was an experimental research with the use of post test only control group design. The research was carried out by using all active students member of SAU Badminton Undiksha (total: 18 students) as the subjects. The subjects were divided into 3 groups: control group, experimental group 1, and experimental group 2.

Selection of samples was done by random sampling. The objects in the study were the tempo of the music being listened to and the reaction time.

Inclusion criteria employed in this study include ages 1825 years and active in badminton sport activities. Exclusion criteria in this study include refusal to be sampled, in a state of illness, fasting, or taking stimulant drugs when measured, or people with permanent brain injury.

The music that was listened to were fast tempo music and slow tempo music. Reaction time measured was simple reaction time (visual and audio) and the measurement was taken with the use of a reaction time meter.

In the experimental group (both experiment 1 and experiment 2) each subject first listened to one type of music at a time (fast tempo for the experiment group 1 and the slow tempo for the experiment group 2), while in the control group each subject was subjected to rest for 5 minutes without listening to any type of music. Then, immediately the visual and audio reaction time of every subject was measured. Each type has 10 times measurement and the procedure was repeated 3 times. The reaction time was calculated from the average reaction time at 30 times measurement ( 3 times repetition with 10 times measurement each).

Data that have been collected in advance were presented descriptively. The next test was to analyze the variant using SPSS v.16 software.

\section{RESULTS AND DISCUSSION}

Data description of reaction time between those that listen to music and those that do not listen to music can be seen in Table 1 below. 
TABLE I. DATA DESCRIPTION OF REACTION TIME BETWEEN DO NOT LISTEN TO MUSIC VS LISTEN TO MUSIC

\begin{tabular}{|c|l|c|c|c|}
\hline $\begin{array}{c}\text { Type of } \\
\text { reaction } \\
\text { time }\end{array}$ & \multicolumn{1}{|c|}{ Group } & N & mean & SD \\
\hline \multirow{2}{*}{ Audio } & $\begin{array}{l}\text { Do not listen to music } \\
\text { (control group) }\end{array}$ & 6 & 339.58 & 46.99 \\
\cline { 2 - 5 } & $\begin{array}{l}\text { Listen to music } \\
\text { (experiment group 1 and 2) }\end{array}$ & 12 & 357.76 & 71.04 \\
\hline \multirow{2}{*}{ Visual } & $\begin{array}{l}\text { Do not listen to music } \\
\text { (control group) }\end{array}$ & 6 & 316.58 & 45.01 \\
\cline { 2 - 5 } & $\begin{array}{l}\text { Listen to music } \\
\text { (experiment group 1 and 2) }\end{array}$ & 12 & 329.60 & 58.67 \\
\hline
\end{tabular}

Based on Table 1, the number of subjects who did not listen to music and the number of subjects who listen to music can be seen. The table shows that the average reaction time ranges from 316.58 to 357.75 , with the visual reaction time always higher than the audio reaction time in both groups.

Comparison of reaction time between both groups was analyzed by t-test and the result is shown in Table 2 below.

TABLE II. T-TEST RESULTS BETWEEN THOSE THAT DO NOT LISTEN TO MUSIC VS THOSE THAT LISTEN TO MUSIC

\begin{tabular}{|c|c|c|c|c|c|c|}
\hline & $\begin{array}{c}\text { Levene's } \\
\text { Test }\end{array}$ & \multicolumn{5}{|c|}{ t-test for Equality of Means } \\
\cline { 3 - 7 } $\begin{array}{c}\text { Type of } \\
\text { reaction } \\
\text { time }\end{array}$ & Sig. & $\begin{array}{c}\text { Sig. (2- } \\
\text { tailed) }\end{array}$ & $\begin{array}{c}\text { Mean } \\
\text { Difference }\end{array}$ & $\begin{array}{c}\text { Std. Error } \\
\text { Difference }\end{array}$ & \multicolumn{2}{|c|}{$\begin{array}{c}\text { 95\% } \\
\text { Confidence } \\
\text { Interval }\end{array}$} \\
\cline { 5 - 8 } & & & & & Lower & Upper \\
\hline Audio & 0.134 & 0.581 & -18.18 & 32.24 & -86.54 & 50.17 \\
\hline Visual & 0.820 & 0.641 & -13.02 & 27.38 & -71.07 & 45.03 \\
\hline
\end{tabular}

Based on Table 2 above, it can be seen that the variation between the two groups is equivalent for both the audio reaction time and the visual reaction time. Based on t-test analysis, it can be deduced that reaction time between the two groups does not have significant variation $(>0,05)$, both at audio and visual reaction time. The comparison of the intergroup reaction time can be seen in Table 3 below.
TABLE III. DATA DESCRIPTION OF REACTION TIME BETWEEN GROUPS

\begin{tabular}{|c|c|c|c|c|c|c|c|}
\hline \multirow{2}{*}{$\begin{array}{l}\text { Type of } \\
\text { reaction } \\
\text { time }\end{array}$} & \multirow{2}{*}{ Group } & \multirow{2}{*}{$\mathbf{N}$} & \multirow{2}{*}{ Mean } & \multirow{2}{*}{ SD } & \multirow{2}{*}{$\begin{array}{l}\text { Std. } \\
\text { Error }\end{array}$} & \multicolumn{2}{|c|}{$\begin{array}{c}\text { 95\% Confidence } \\
\text { Interval for } \\
\text { Mean }\end{array}$} \\
\hline & & & & & & $\begin{array}{l}\text { Lower } \\
\text { Bound }\end{array}$ & $\begin{array}{l}\text { Upper } \\
\text { Bound }\end{array}$ \\
\hline \multirow[t]{3}{*}{ Audio } & Control & 6 & 339.58 & 46.99 & 19.18 & 290.26 & 388.89 \\
\hline & Experiment 1 & 6 & 363.15 & 62.64 & 25.57 & 297.40 & 428.89 \\
\hline & Experiment 2 & 6 & 352.37 & 84.30 & 34.41 & 263.89 & 440.84 \\
\hline \multirow[t]{3}{*}{ Visual } & Control & 6 & 316.58 & 45.01 & 18.37 & 269.33 & 363.81 \\
\hline & Experiment 1 & 6 & 335.34 & 60.96 & 24.88 & 271.35 & 399.31 \\
\hline & Experiment 2 & 6 & 323.86 & 61.46 & 25.09 & 259.36 & 388.36 \\
\hline
\end{tabular}

Based on Table 3 it can be deduced that the mean value of audio type of reaction time has variation with the smallest value in the control group $(339.58 \mathrm{~ms})$ and that the largest value was in the fast tempo group (363.15ms). For the visual type, the average reaction time also has relative variation with the smallest value being in the control group (316.58ms) and the largest value was in the fast tempo group $(335.34 \mathrm{~ms})$. There are similarities in the mean of both audio and visual type of the reaction time sequence ranging from the smallest to the biggest: the control group, the slow tempo group, and the fast tempo group. The result of variance analysis test is as shown in table 4 below.

TABLE IV. ANALYSIS OF VARIANCE ON REACTION TIME

\begin{tabular}{|c|c|c|c|c|c|c|}
\hline $\begin{array}{c}\text { Type of } \\
\text { reaction } \\
\text { time }\end{array}$ & & $\begin{array}{c}\text { Sum of } \\
\text { Squares }\end{array}$ & Df & $\begin{array}{c}\text { Mean } \\
\text { Square }\end{array}$ & F & Sig. \\
\hline \multirow{4}{*}{ Audio } & Between Groups & 1670.904 & 2 & 835.452 & .189 & .829 \\
\cline { 2 - 7 } & Within Groups & 66203.067 & 15 & 4413.538 & & \\
\hline \multirow{3}{*}{ Visual } & Total & 67873.971 & 17 & & & \\
\cline { 2 - 8 } & Within Groups & 47601.566 & 15 & 3173.438 & & .846 \\
\cline { 2 - 8 } & Total & 48674.962 & 17 & & & \\
\cline { 2 - 8 } & & 1073.397 & 2 & 536.698 & .169 & .820 \\
\hline
\end{tabular}

From table 4, the significant value of variance analysis test for both audio and visual reaction time was observed to be greater than $0.05(0.829$ and 0.846$)$. It can be concluded that there was no significant difference in mean reaction time between the three groups (control group, fast tempo group, and slow tempo group) for both the audio and the visual types.

[5] in his research of 30 subjects, found that simple reaction time was more slowly when listening to rock music than before listening to rock music. The reaction times in this study were 
measured as soon as they were listening to music. It is possible that the music effects heard did not affect the reaction time.

[8] found that the flow of techno music increases the time of visual reactions. However, in this study, there was measurement of reaction time about 45 seconds after the music was turned off, where the techno music stream was first heard for 30 minutes. In this study, the music was only listened for 5 minutes and then the measurement was done immediately (less than 30 seconds). The record of insignificant results, in this study, may be as a result of short exposure time in addition to time measurement factors.

The results of the study by [3] found that the control group (the group that did not listen to music) had greater and more significant scores on false responses and negligible responses than experimental groups (groups listening to reggae, classical or rock music). Research by [3] made use of a more complex response because there was requirement for response consideration. When compared with this insignificant research results, it may be as a result of different types of reaction time. On simple reaction, the differences in the intervention group and the control group tends to be insignificant. However, on more complex reactions, it has the possibility of having good effect. A systematic review by [4] on the effects of music and sound on human performance comes up with a conclusion that musical effects on occupations that require concentration of the nature of the music disorder inhibit a cautious response. The volume of medium music can support concentration due to increased comfort. But music with loud volume suppresses the response of vigilance. Based on this, it can be concluded that the influence of music strongly supports concentration due to occurrence of psychological effects (giving comfort) on the subject. Rigg states that music that has the potential of increasing concentration is a type of music that has no lyrics (instrumental music), while music that has lyrics can interfere with concentration. This may be because the music with the lyrics causes the subject to be divided in concentration as a result of the need to process the information contained in the lyrics. This study entirely uses music that has lyrics and has a tendency of influencing disorder, but in short exposure.

Insell et al. in their research on subjects who are undergoing treadmill found that music only affects the psychological aspect (RPE or perceived exercise rating), not on the physiological aspect (time to target heartbeat). Their research showed that the tempo of music only affects psychological factors with no significant effects on. It can be concluded that if the amount of reaction time is considered to be influenced by physiological factors and psychological factors, then the tempo of music tends to affect only psychological factors.

Similar results were obtained by Han et al where the reaction time of the three types of musical tempos was not significantly different when compared. The difference is just that the research carried out by Han et al did not involve control conditions (not listening to music). Research by Chandler and Guillory found that most types of music tested (4 of 5 types of music) got insignificant results compared to controls. Only folk type music gets 0.32 seconds. Based on these two results, the type of musical tempo tends not to have a significant effect on reaction time. Other results obtained from research by Chandler and Guillory are calm classical type of music that reacts to reaction time faster than the intense classical music type ( 0.34 seconds vs 0.41 seconds). The results are similar to the results of this study where in this study reaction time on subjects who listen to slow tempo music tend to be smaller than the reaction time on subjects who listen to music fast tempo although it was insignificant. A conclusion can be reached that tempo differences tend not to have significant effect on simple reaction time.

\section{CONCLUSIONS AND RECOMMENDATIONS}

1. The average reaction time ranged from $316.58 \mathrm{~ms}$ to $357.75 \mathrm{~ms}$.

2. No significant difference in reaction time was observed between groups not listening to music with groups listening to music either for audio or visual time reactions.

There was, also, no significant difference observed in reaction time between the three groups experimented on (control group, fast tempo group, and slow tempo group) for both the audio and the visual type.

Based on the results obtained in this study, some suggestions that can be proposed include: (1) A similar research needed to be carried out on more subjects to confirm the results of this study; (2) it is necessary to conduct research with the same variable object in other population groups to see the consistency of the effect of listening to music on simple reaction time.

\section{REFERENCE}

[1] DT Bishop, et al. Effects of musically-induced emotions on choice reaction time performance. The Sport Psychologist, 2009, 23, 1-19.

[2] N Chandler, and C. Guillory. "The effect of music on basic human reaction time," Tersedia pada: http://cssf.usc.edu/History/2013/Projects/S0403.pdf Diakses pada tanggal 10 November 2016.

[3] M Chraif, et al. "The effects of music exposure in time reaction to multipli stimuli," Romanian Journal of Experimental Applied Psychology. 2013. Vol.4 Issue 4.

[4] BH Dalton dan DG Behm. Effects of noise and music on human and task performance: A systematic review. Occupational Ergonomics 143152. 2007.

[5] DA Dewa, et al. Pengaruh musik rock terhadap waktu reaksi sederhana. Tersedia pada: http://repository.maranatha.edu/19937/ Diakses pada tanggal 10 November 2016.

[6] I Han, et al. The physiological response to music tempo: The investigation of the "pump-up" song. Physiology 435, Sec 602, Group 5.http://jass.neuro.wisc.edu/2011/01/The\%20Physiological\%20Respon se\%20to\%20Music\%20Tempo,\%20The\%20Investigation\%20of\%20th e\%20\%E2\%80\%9CPump-Up\%E2\%80\%9D\%20Song.pdf Diakses pada tanggal 10 November 2016

[7] RJ Kosinski. “A Literature Review on Reaction Time," Tersedia pada: http://homepage.univie.ac.at/andreas.franz.reichelt/intro2cogsci2/data/1 iterature_review_reaction_time.pdf Diakses tanggal 30 Oktober 2015

[8] M Meško, et al. 2009. The Effect of Listening to Techno Music on Reaction Times to Visual Stimuli. Acta Univ. Palacki. Olomuc., Gymn., vol. 39, no. 1. P.67-73.

[9] L. Rigg, Does Music Affect Concentration Levels And Mental Performance?. Tersedia pada: https://www.lshtm.ac.uk/aboutus/introducing/public engagement/workingwithschools/youngscientistsprogramme/pastproje cts/does_music_affect_concentration_lola_rigg.pdf Diakses pada tanggal 10 November 2016

[10] G. H. Szinnai, et al. "Effect of water deprivation on cognitive motor performance in healthy men and women," The American Journal of Physiology 289(1): R275-280. Bishop DT, et al. 2009. Effects of musically-induced emotions on choice reaction time performance. The Sport Psychologist, 2009, 23, 1-19 